PACS: 42.25.Fx, 42.30.Kq, 42.30.Lr.

UDC: $537.86,535.42,535.4$

\title{
Reflected energy flux anomaly under grazing incidence: the Brewster angle analogy
}

\author{
T. Rokhmanova, A.V. Kats \\ O.Ya. Usikov Institute for Radiophysics and Electronics, NAS of Ukraine, Proskura st. 12, 61085 Kharkiv, Ukraine \\ rokhmanova@ieee.org
}

ORCID: 0000-0002-9757-3731

DOI: $10.26565 / 2222-5617-2019-30-04$

The paper presents thorough theoretical and numerical analysis of the anomalies accompanying light diffraction on periodical structures (gratings). We have developed appropriate theoretical approach allowing to consider strong anomalous effects. Obtained results are presented in the form of analytical expressions for the quntities of interest, both diffracted field amplitudes and the outgoing waves energy fluxes. It is proved existence of the fluxes extrema at the specific grazing angle of incidence 6 or wavelength. Namely, the specular reflection can be suppressed even for rather shallow gratings up to approximately total suppression.This effect is accompanied by essential energy redistribution between all outgoing waves depending on the grating profile. It is of essence that the energy maxima exist in all nonspecular diffraction orders at the same point (angle, wavelength) as the minimal specular reflectivity. For small period gratings, such that there do not exist other outgoing waves except the specular one, the reflectance minimum is attended by approximately total absorption of the incident radiation. Thus, we show that the grazing anomaly (GA) can be accompanied by redirection of the incident wave energy into nonspecular diffraction channels and into absorption. The results are applicable in the wide spectral region, from visible and near-infrared to terahertz and high-frequency regions for metals and semiconductors with high permittivity.

The anomaly considered is well expressed for high electromagnetic contrast of the adjacent media, say, air and metal or semiconductor. Then the high contrast is due to the high value of the metal/semiconductor dielectric permittivity $\varepsilon,|\varepsilon| \gg 1$, and the anomaly corresponds to incidence of TM polarized wave. It is shown that the grazing anomaly (GA) is of rather general type and can take place if other than the specular diffraction order experiencies grazing propagation also. This property follows from the results obtained by strict application of the optical reciprocity theorem to the geometry under consideration.

The specific case of harmonic relief grating is discussed in detail. It is demomstrated existence of the characteristic inclination, $a_{c r}$, of the relief inclinatuion for the grating period comparable with the incident radiation wavelength, $a_{c r} \simeq \sqrt{|\xi|} \ll 1$, where $\xi$ stays for the surface impedance, $\xi=1 / \sqrt{\varepsilon}$. The condition $a \sim a_{c r}$, or greater, corresponds to highly expressed GA. The theoretical results are illustrated by numerical applications to gratings on Culvacuum (air) interface in $\mathrm{THz}$ region.

The results obtained can be simply transferred to the TE polarized waves. For this we have to consider the adjacent media with high contrast magnetic properties, i.e., high value of the magnetic permeability $\mu,|\mu| \gg 1$. This case is of high interest for nowaday applications in nanophotonics and metamaterials development.

As compared with other anomalies GA is attributed to the resonance-type behaviour of the energy flux, not wave amplitudes, the latter change monotonically within this anomaly contrary to the well known Rayleigh and resonance anomalies, where the wave amplitude experiences fast nonmonotonous dependence on the angle of incidence and wavelength.

Keywords: diffraction grating, energy flux anomaly, resonance.

\section{Аномалія в потоці відбитої енергії при ковзному падінні: аналогія 3 кутом Брюстера}

\author{
Т.М. Рохманова, О.В. Кац \\ Інститут радіофізики та електроніки ім. О.Я. Усикова НАН Украӥни, вул. Проскура 12, 61085 Харків, Украӥна
}

У статті наведений докладний теоретичний та чисельний аналіз аномалій, які супроводжують дифракцию світла на періодичних структурах (гратках). Розвинуто необхідний для розглядання суттєвих аномалій теоретичний підхід. Отримані результати наведені у формі аналітичних виразів для параметрів, що уявляють фізичний інтерес, таких, як амплітуди хвиль та потоки енергії хвиль, які віддаляються від межі поділу. Доведено наявність екстремумів за кутом ковзання та довжиною хвилі у потоків енергії. Зокрема, навіть для вельми пологих граток можливим виявляється заглушення дзеркального відбивання до майхе повного заглушення. Цей ефект супроводжується суттєвим перерозподілом енергії поміж хвилями, що віддаляються, який виявляється вельми чутливим до профіля гратки (ії Фурьє спектру). Максимуми енергії недзеркальних компонент розташовані в тій же точці (за кутом падіння та довжиною хвилі), що й мінімум дзеркального відбивання. 
Дифракція на гратках з малим періодом, таких що крім дзеркально відбитої хвилі не існує інших хвиль, що розповсюджуються, мінімум дзеркального відбивання супроводжується майже повним поглинанням падаючого випромінювання. Таким чином, доведено, що ковзна аномалія (GA) супроводжується перерозподілом енергії хвилі,що падає, в недзеркальні дифракційні канали, а також у поглинання. Результати $є$ дійсними у широкомуспектральноіу діапазоні, від видимого та ближнього ІК до терагерцового та НВЧ діапазонів для металів та напівпровідників 3 високою діелектричною проникністю.

GA добре виражена при високому електромагнітному контрасті суміжних середовищ, наприклад, повітря 3 металом чи напівпровідником. При цьому високий контраст забезпечується великим значенням діелектричної проникності метала (напівпровідника) $\varepsilon,|\varepsilon| \gg 1$, а аномалія виникає при падінні ТМ поляризованої хвилі. Продемонстровано, що GA $\epsilon$ доволі зпгальною аномалією і може спостерігатися також за умов, коли один з дифракційних порядків відповідає ковзній хвилі. Ця властивість виходить 3 наведених результатів шляхом застосування оптичної теореми взаємності к геометрії, що досліджена.

Детально розглянутий випадок граток з гармонійним профілем. Виявлена наявність характерноно нахилу $a_{c r}$ для граток, просторовий період яких є зіставним 3 довжиною падаючого випромінювання, $a_{c r} \simeq \sqrt{|\xi|} \ll 1$, де $\xi$ означає поверхневий імпеданс, $\xi=1 / \sqrt{\varepsilon}$. Умова $a \sim a_{c r}$ ( $a$-- нахил гратки, що розглядається) або більше відповідає яскраво вираженій аномалії. Результати теоретичного розглядання ілюструються прикладами чисельних розрахунків у терагерцовому діапазоні довжин хвиль для граток на поверхні міді, яка межує з вакуумом(повітрям) .

Отримані результати дозволяють простий переніс на випадок ТЕ поляризованих хвиль. Для цього необхідно розглянути межуючі середовища 3 аисоким контрастом магнітних властивостей, коли одне 3 них має високу магнітну проникність $\mu,|\mu| \gg 1$. Цей випадок $\epsilon$ вельми цікавим для сучасних застосувань в нанофотоніці, а також при створенні наноматеріалів.

На відміну від інших аномалій GA обумовлена резонансних характером поведінки потоку енергії, а не амплітуди відповідної хвилі. В околі GA амплітуди хвиль змінюються монотонно, у протилежності до того, що має місце в околах Релеївської та резонансної аномалій, де амплітуда відповідної хвилі змінюється швидко та немонотонно із зміною кута падіння або довжини хвилі.

Ключові слова: дифракційна гратка, аномалія потоку енергії, резонанс.

\title{
Аномалия в потоке отраженной энергии при скользящем падении: аналогия с углом Брюстера
}

\author{
T.Н. Рохманова, А.В. Кац \\ Институт радиофизики и электроники ии. О.Я. Усикова НАН Украины, ул. Проскура 12, 61085 Харьков, Украина
}

В статье представлен подробный теоретический и численный анализ аномалий, сопровождающих дифракцию света на периодических структурах (решетках). Развит необходимый для описания сильных аномалий теоретический подход. Полученные результаты представлены в форме аналитических выражений для представляющих физический интерес параметров, таких как амплитуды волн и потоки энергии уходящих от границы волн. Доказано наличие экстремумов у потоков энергии по углу скольжения и длине волны. В частности, даже для весьма пологих решеток возможно подавление зеркального отражение вплоть до почти полного подавления. Этот эффект сопровождается существенным перераспределением энергии между уходящими от границы волнами, весьма чувствительным к профилю решетки (ее Фурье спектру). Максимумы энергии незеркальных компонент расположены в той же точке (по углу падения и длине волны), что и минимум зеркального отражения.

У решеток с малым периодом, таких, что не существует других уходящих волн, кроме зеркальной, минимум зеркального отражения сопровождается почти полным поглощением падающего излучения. Таким образом показано, что "скользящая аномалия" (GA) может сопровождаться перераспределением энергии падающей волны в незеркальные диффракционные каналы и в поглощение. Результаты применимы в широком спектральном диапазоне, от видимого и ближнего ИК до терагерцового и СВЧ диапазонов для металлов и полупроводников с высокой диэлектрической проницаемостью.

GA хорошо выражена при высоком электромагнитном контрасте примыкающих сред, например, воздуха и металла или полупроводника. При этом высокий контраст обусловливается высоким значением диэлектрической проницаемости металла (полупроводника) $\varepsilon,|\varepsilon| \gg 1$, а аномалия возникает при падении TM поляризованной волны. Показано, что GA является аномалией весьма общего типа и может также наблюдаться, когда один из дифракционных порядков соответствует скользящей волне. Это свойство следует из полученных результатов путем применения оптической теоремы взаимности к исследованной геометрии.

Детально рассмотрен случай решеток гармонического профиля. Выявлено наличие характерного наклона $a_{c r}$ для решеток, период которых сравним с длиной падающей волны, $a_{c r} \simeq \sqrt{|\xi|} \ll 1$, где $\xi$ обозначает поверхностный импеданс, $\xi=1 / \sqrt{\varepsilon}$. Условие $a \sim a_{c r}$ ( $a-$ наклон рассматриваемой решетки) или больше соответсвует ярко выраженноой аномалии. Результаты теоретического рассмотрения иллюстрируются примерами численных расчетов для решеток на поверхности меди, граничащей с вакуумом (воздухом) в терагерцовом диапазоне длин волн. Полученные результаты допускают простой перенос на случай ТЕ поляризованных волн. Для этого необходимо рассмотреть прилегающие среды с высоким контрастом 
магнитных свойств, когда одна из сред имеет высокую магнитную проницаемость, $\mu,|\mu| \gg 1$. Этот случай представляет значительный интерес для современных приложений в нанофотонике, а также при создании метаматериалов.

В отличие от других аномалий, GA обусловлена резонансным характером поведения потока энергии, а не амплитуды соответствущей волны. В окрестности GA амплитуды волн изменяется монотонно, в противоположность тому, что в окрестностях Рэлеевской и резонансной аномалий амплитуда соответствующей волны меняется быстро и немонотонно с изменением угла падения или длины волны.

Ключевые слова: дифракционная решетка, аномалия потока энергии, резонанс.

Introduction. Classification of anomalies.

The pioneering work on anomalies in light diffraction on metal gratings was performed by R. Wood in 1902 [1], while the first physical interpretation of some of the observed peculiarities was presented in 1907 by Lord Rayleigh [2]. The latter associated them with the transition from the outgoing wave to the evanescent (decaying) one and vice versa in different diffracted orders. However, such explanation was insufficient and other possibility was proposed by U. Fano [3] who attributed some of Wood anomalies to the resonance excitation of the surface electromagnetic waves (surface plasmon polaritons, SPP, [4].) at the metal-air interface. Also, Wood discovered one more anomaly related to the unexpectedly high intensity of the grazing outgoing wave [5]. Below the anomalies attributed to the grazing propagating waves are referred to as GA (Grazing Anomaly), see [6-8]. Up to now, Wood anomalies are widely discussed due to their perspective role in nanophysics and, particularly, nanophotonics.

Existing for an arbitrary interface and light polarization, the Rayleigh anomaly is much more pronounced for the high-dielectric contrast interface, for TM (transverse magnetic) polarization and nonmagnetic media. Below, we restrict the consideration to the nonmagnetic case only. The results for the magnetic case can be obtained by replacing the dielectric permittivity, $\varepsilon$, with the magnetic permeability, $\mu$, and the TM polarization by the TE one and vice versa. It worth mentioning that the resonance anomaly can exist only for such interfaces that support surface electromagnetic waves (SEW) and that GA anomaly is rather universal and is well expressed for high contrast interfaces for TM polarization [6].

Consider briefly the main properties of these anomalies. The branch (Rayleigh) point anomaly is of general type, its position can be easily obtained from the Bragg diffraction conditions and it exists for arbitrary polarization and interfaces. However, it is more pronounced for metals under TM polarization. At the Rayleigh point the derivative of the diffracted wave intensity with respect to the wavelength or angle of incidence turns infinity. The resonance anomaly is less general because it is caused by existence of well-defined eigenmodes of the interface. For isotropic and nonmagnetic dissipation-free media such surfacelocalized electromagnetic waves do exist under the conditions $\varepsilon<0, \varepsilon_{d}>0, \varepsilon_{d}+\varepsilon<0$, where $\varepsilon$ and $\varepsilon_{d}$ denote dielectric permittivity of the metal and the adjacent dielectric, respectively. The SPP in-plane wavenumber, $Q=\frac{\omega}{c} \sqrt{\varepsilon \varepsilon_{d} /\left(\varepsilon+\varepsilon_{d}\right)}>0$, where $\omega$ is the (angular) frequency of the incident wave, exceeds the wavenumber of the adjacent dielectric volume wave with the same frequency, $k=\omega \sqrt{\varepsilon_{d}} / c, Q>k$. The square root symbol stays for the main branch, so that $\sqrt{Z}=\sqrt{|Z|} \exp (i \phi / 2)$ for $Z=|Z| \exp (i \phi)$ with $\phi \in[0,2 \pi)$. The SPP is orthogonally $\mathbf{H}$ polarized, i.e., if it propagates along the interface $z=0$ in $O x$ direction then its magnetic field, $\mathbf{H}$, is directed along $O y$ direction, $\mathbf{H}=(0, H, 0)$, and the electric field, $\mathbf{E}$, lies in the $x O z$ plane, $\mathbf{E}=\left(E_{x}, 0, E_{z}\right)$. The space dependence of the SPP fields in the dielectric halfspace, $z \leq 0$, is given by the ansatz $\exp [i Q x-i p(Q) z]$, where the function $p(\mathbf{q})$ is defined for arbitrary two-dimensional vector $\mathbf{q}=\left(q_{x}, q_{y}\right)$ so that,

$$
p(\mathbf{q})=\sqrt{k^{2}-\mathbf{q}^{2}}, k=\sqrt{\varepsilon_{d}} \omega / c, \operatorname{Re}, \operatorname{Im} p(\mathbf{q}) \geq 0 .
$$

In the specific case of SPP, the quantity $p(Q)$ is $z$ component of the wavevector in the dielectric and for dissipation-free media it is pure imaginary under the condition $\varepsilon+\varepsilon_{d}<0, \quad p(Q)=i|p(Q)|$, so that the field amplitude decays exponentially with increasing distance from the interface $z=0$.

Recall, if the plane monochromatic electromagnetic wave with space dependence,

$$
\mathbf{E}, \mathbf{H} \propto \exp [i(\mathbf{q} \cdot \mathbf{r})+i p(\mathbf{q}) z], \quad \mathbf{q}=\left(q_{x}, q_{y}\right),
$$

(here and further the time dependence is supposed to be of the form $\exp (-i \omega t)$ and is omitted) is incident on the interface from the dielectric medium located at negative $z$ values, $-\infty<z<\zeta(x)$, where the surface profile, $z=\zeta(x)$, presents periodic function with period $d$, $\zeta(x+d)=\zeta(x)$, then the electromagnetic field within the dielectric medium is the sum of spatial harmonics of the form, 


$$
\begin{gathered}
\mathbf{E}_{n}, \mathbf{H}_{n} \propto \exp \left[i\left(\mathbf{q}_{n} \cdot \mathbf{r}\right)-i p\left(\mathbf{q}_{n}\right) z\right], \\
\mathbf{q}_{n}=\mathbf{q}+n \mathbf{g}, \quad \mathbf{g}=\mathbf{e}_{x} 2 \pi / d, \quad n=0, \pm 1, \pm 2, \ldots
\end{gathered},
$$

where $\mathbf{e}_{x}$ is the unit vector directed along the $O x$ axis. In other words, the diffracted field is given by the FloquetFourier expansion, [9, 11]. In (3) the sign minus before $p\left(\mathbf{q}_{n}\right)$ stays to satisfy the radiation boundary conditions at $z=-\infty$. Restriction of the outgoing waves (and evanescent decaying ones) within the whole halfspace $z \leq \zeta(x)$ corresponds to use of the Rayleigh hypothesis, [2], and is not restrictive even for rather deep gratings, see recent discussion in $[9,11,12]$.

If for some specific integer $n$ the condition $\left|\mathbf{q}_{n}\right| \simeq Q$ holds true, then for the appropriate polarization of this diffracted wave the resonance excitation of SPP takes place. SPP is an evanescent wave so the magnitude of the corresponding diffracted order can exceed that of the incident wave. Specifically, in the simplest geometry, when $\mathbf{q}$ is orthogonal to the grating grooves, only TM component of the incident wave can excite the SPP.

We would like to underline that the Rayleigh and the resonance anomalies are related to the specific and rather sharp dependence of the field amplitudes on the wavelength and angle of incidence. They can be considered on the basis of simple qualitative treatment. The treatment of the third mentioned Wood anomaly cannot be accomplished without a thorough theoretical investigation. This obstacle is caused by the fact that the field amplitude changes monotonically within the anomaly. It can be shown that the corresponding quasiresonance behavior is characteristic for the intensity, not for the field amplitude. The method for considering this and other diffraction anomalies analytically was presented in [8], see also a more detailed consideration in [13-15].

\section{Grazing incidence anomaly.}

Consider the case of the simplest geometry for TM polarized waves with magnetic field orthogonal to the plane of incidence, so that for the incident wave, $\mathbf{H}^{i}$, and for the Fourier-Floquet expansion of the diffracted field, $\mathbf{H}^{D}$, we have,

$$
\begin{aligned}
\mathbf{H}^{i} & =\mathbf{e}_{y} H \exp [i q x+i p(q) z], \\
\mathbf{H}^{D} & =\mathbf{e}_{y} \sum_{n=-\infty}^{\infty} H_{n} \exp \left[i q_{n} x-i p\left(q_{n}\right) z\right], \quad z \leq \zeta(x),
\end{aligned}
$$

where $q_{n}=q+n g$. Note, the diffracted field in (4) and below in (5) includes only outgoing (and evanescent) waves, i.e., here we use the Rayleigh hypothesis, [2], restricting the expansion to the terms with $z$-dependence of the form $\exp \left[-i p\left(q_{n}\right) z\right]$ only, and omitting those with $z$-dependence of the alternative form, $\exp \left[i p\left(q_{n}\right) z\right]$. This guarantees fulfillment of the boundary (radiation) conditions at $z=-\infty$.

The electric field, $\mathbf{E}=\left(E_{x}, 0, E_{z}\right)$, and can be easily obtained from (3) and Maxwell equation. Specifically, the electric component of the diffracted field can be presented in the series of the form coinciding with that of $\mathbf{H}^{D}$,

$$
\mathbf{E}^{D}=\sum_{n=-\infty}^{\infty} \mathbf{E}_{n} \exp \left[i q_{n} x-i p\left(q_{n}\right) z\right], z \leq \zeta(x)
$$

At the interface the total fields, $\mathbf{H}=\mathbf{H}^{i}+\mathbf{H}^{D}$, $\mathbf{E}=\mathbf{E}^{i}+\mathbf{E}^{D}$, are to satisfy the impedance boundary conditions, [16],

$$
\mathbf{E}_{t}=\xi[\mathbf{n} \times \mathbf{H}] \text { for } z=\zeta(x),
$$

where the subindex $t$ denotes tangential to the interface component of the corresponding vector, $\xi$ denotes the surface impedance, and $\mathbf{n}$ stays for the unit vector normal to the interface directed into the dielectric. We use Gauss units so that the surface impedance $\xi$ is dimensionless, and for nonmagnetic media $\xi=\sqrt{\varepsilon_{d} / \varepsilon}$.

The profile Fourier series expansion is

$$
\begin{gathered}
\zeta(x)=\sum_{n=-\infty}^{\infty} \zeta_{n} \exp (\text { ingx }), g=2 \pi / d>0, \\
\zeta_{-n}=\zeta_{n}^{*}, \quad \zeta_{0}=0
\end{gathered}
$$

The condition $\zeta_{0}=0$ corresponds to the specific choice of $\mathrm{Oz}$ axis origin. The Fourier series coefficients of the interface normal, $\mathbf{n}=\mathbf{n}(x)$, can be expressed in terms of $\zeta_{n}$.

Substituting into Eq. (6) the fields representations given in Eqs. (4), (5), expressing the electric field Fourier amplitudes, $\mathbf{E}_{n}$, in terms of the magnetic ones, $H_{n}$, and equating terms with equal space dependence, we arrive at the infinite system of linear algebraic equations for the transformation coefficients (TCs), $h_{n}=H_{n} / H$,

$$
\sum_{m=-\infty}^{\infty} D_{n m} h_{m}=V_{n}, \quad n=0, \pm 1, \pm 2, \ldots,
$$

where the matrix of the system, $\hat{D}=\left\|D_{n m}\right\|$, and the righthand side column vector, $\hat{V}=\operatorname{col}\left\{V_{n}\right\}$, represent functionals depending on the problem parameters, specifically, the interface profile $\zeta(x)$. The coefficients of the system allow infinite series expansions with respect 
to $\zeta_{n}$. It is essential that strong diffraction anomalies take place for rather shallow gratings such that $k|\zeta|,|d \zeta / d x| \ll 1$, see [11-13] and below, so the expansions are very useful. For shallow gratings under discussion, we can restrict the series expansions of the coefficients to the main (linear) terms only, so that

$$
\begin{gathered}
D_{n m}=\left(\beta_{n}+\xi\right) \delta_{n m}-i\left(1-\alpha_{n} \alpha_{m}\right) \mu_{n-m} \\
n, m=0, \pm 1, \pm 2, \ldots \\
V_{n}=\left(\beta_{n}-\xi\right) \delta_{n 0}+i\left(1-\alpha_{n} \alpha_{0}\right) \mu_{n} \\
n=0, \pm 1, \pm 2, \ldots
\end{gathered}
$$

Here $\delta_{n m}$ stays for the Kronecker delta-symbol, and

$$
\begin{gathered}
\mu_{n}=k \zeta_{n}, \quad \alpha_{n}=\alpha+n \kappa, \quad \kappa=g / k \\
\beta_{n}=\sqrt{1-\alpha_{n}^{2}}, \operatorname{Re}, \operatorname{Im} \beta_{n} \geq 0, \\
n=0, \pm 1, \pm 2, \ldots, \quad n \in \mathbb{Z}
\end{gathered}
$$

where $\alpha=\sin \theta, \theta$ denotes the incidence angle, $\mathbb{Z}$ stays for the set of integers.

Consider here the simplest (but of high interest) case of the grazing incidence, $0<\beta \ll 1(0<1-\alpha \ll 1)$. That is the specular reflected wave with necessity is the grazing one. The simplest geometry of the problem is such, when only one of the diffracted waves except the specular wave is outgoing from the interface, all other diffraction orders correspond to evanescent waves. This geometry is presented in Fig. 1.

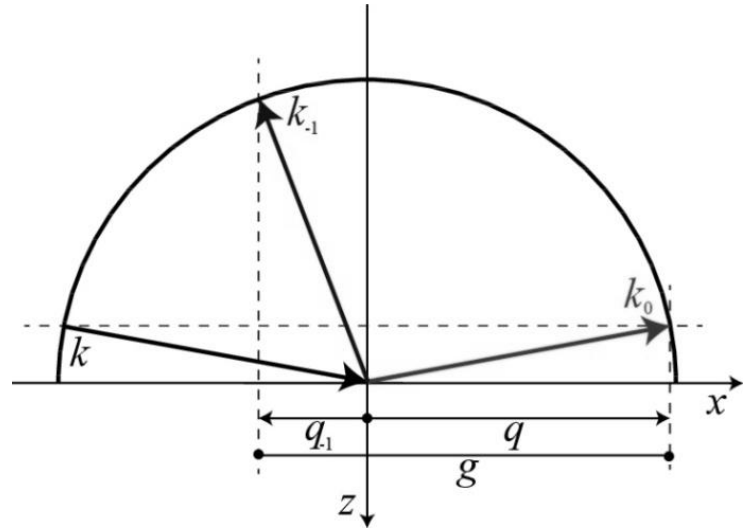

Fig. 1. Grazing incidence diffraction. The grating spacing, $d$, is supposed to be such that except the specular wave only the minus first diffraction order presents propagating wave, other diffraction orders correspond to evanescent ones, i.e., at $q \simeq k, \quad q_{1}=q+g>k,\left|q_{-1}\right|=|q-g|<k$, and $\left|q_{n}\right|>k$ for all $n \neq-1,0$.

It should be emphasized, that among diffracted waves only the specular reflected one is close to the corresponding Rayleigh point, $\beta=\beta_{0} \ll 1$, and all other waves are far enough from their branch points. That is, the only one diagonal element of the matrix $\hat{D}=\left\|D_{n m}\right\|$, where $\mathrm{N}$ and $\mathrm{M}$ are nonzero iterger numbers $(N, M \neq 0$ ).The submatrix $\hat{\bar{D}}$ is diagonally dominat due to the fact that all nondiagonal elements are small as compared with unity and all diagonal ones are of order unity or greater. Thus, it can be easily inversed by means of the regular series expansion. So, one can obtain the solution in the form

$$
h_{0}=\frac{\beta-\xi_{\text {eff }}}{\beta+\xi_{\text {eff }}},
$$

$$
h_{M}=\frac{2 i \beta}{\beta+\xi_{\text {eff }}} U_{M}, \quad M= \pm 1, \pm 2, \ldots,
$$

where

$$
\begin{gathered}
\xi_{\text {eff }}=\xi+\Gamma, \\
\Gamma=\sum_{M, L \neq 0}\left[\hat{\bar{D}}^{-1}\right]_{M L}\left(1-\alpha_{0} \alpha_{M}\right)\left(1-\alpha_{L} \alpha_{0}\right) \mu_{L} \mu_{-M}, \\
U_{M}=\sum_{L \neq 0}\left[\hat{\bar{D}}^{-1}\right]_{M L}\left(1-\alpha_{L} \alpha_{0}\right) \mu_{L}, \quad M= \pm 1, \pm 2, \ldots
\end{gathered}
$$

It is essential that the coefficients $U_{M}$ experience only slow dependence on the parameters of interest in the vicinity of the point $\beta=0$, as well as the functions $\Gamma$ and $\xi_{\text {eff }}$.

In what follows we are dealing with rather smooth and shallow gratings. Under this condition we can restrict the $U_{M}$ series expansion by the two first terms only,

$$
\begin{gathered}
U_{M} \simeq b_{M}^{-1}\left[\left(1-\alpha_{M} \alpha_{0}\right) \mu_{M}+\right. \\
\left.+i \sum_{L \neq 0} b_{L}^{-1}\left(1-\alpha_{L} \alpha_{0}\right)\left(1-\alpha_{L} \alpha_{M}\right) \mu_{L} \mu_{M-L}\right] \\
M= \pm 1, \pm 2, \ldots
\end{gathered}
$$

Noteworthy, here the second-order terms are essential if the corresponding Fourier amplitude of the grating, $\mu_{M}$ , vanishes or is anomalously small. Under this condition, the anomalous effects in M-th diffraction order are small and thus of low interest. Therefore, below we restrict our consideration to the linear term of $U_{M}$ expansion.

The main term of the quantity $\Gamma$ expansion is the square one,

$$
\Gamma=\sum_{M \neq 0} b_{M}^{-1}\left(1-\alpha_{0} \alpha_{M}\right)^{2}\left|\mu_{M}\right|^{2}
$$

Emphasize here that the results obtained are actually valid for the arbitrary angle of incidence for which all 
nonspecular reflected waves are far from their Rayleigh and resonance points, i.e., the inequality $\left|\beta_{n}-\xi\right|>>|\xi|$ holds for the integers $n= \pm 1, \pm 2, \pm 3, \ldots$. Only the specular reflected wave can be arbitrary close to the grazing propagation.

\section{Energy flux extremes. Brewster angle analogy.}

Expressions (14), (18) describe the fast dependence of the TCs on the angle of incidence through the quantity $\beta=\cos \theta$ for $\beta \ll 1$. Other functions entering the solution, $U_{N}$, $\xi_{\text {eff }}$, etc., under the condition $\beta \ll 1$ are slow ones and thereby can be approximated by constant values related to the point $\beta=0$. This fact allows performing a thorough analytical investigation of the problem. Starting with the specular reflectivity, $\rho(\beta)$,

$$
\rho(\beta)=\left|h_{0}\right|^{2}=\frac{\left(\beta-\xi_{\text {eff }}^{\prime}\right)^{2}+\xi_{\text {eff }}^{\prime \prime 2}}{\left(\beta+\xi_{\text {eff }}^{\prime}\right)^{2}+\xi_{\text {eff }}^{\prime \prime 2}},
$$

one can see that it possesses specific minimal value at the point, $\beta=\beta_{\text {extr }}$, such that,

$$
\beta_{\text {extr }}=\left|\xi_{\text {eff }}\right|
$$

Here and below the prime (double prime) denotes the real (imaginary) part of the corresponding quantity. In Fig. 2 the specular reflectivity dependence on $\beta$ is presented for harmonic gratings in the vicinity of the point $\beta=0$.

At the extreme point, $\beta=\beta_{\text {extr }}, \quad \rho$ exceeds its minimal value,

$$
\rho_{\text {min }} \equiv \rho\left(\beta_{\text {extr }}\right)=\frac{\left|\xi_{\text {eff }}\right|-\xi_{\text {eff }}^{\prime}}{\left|\xi_{\text {eff }}\right|+\xi_{\text {eff }}^{\prime}} .
$$

The specular TC field at this point is as follows,

$$
h_{0}\left(\beta_{\text {extr }}\right)=\frac{\left|\xi_{\text {eff }}\right|-\xi_{\text {eff }}}{\left|\xi_{\text {eff }}\right|+\xi_{\text {eff }}} .
$$

The $\rho$ dependence on the angle of incidence in terms of the variable $\beta$ is illustrated in Fig. 2. As it strictly follows from Eqs. (18), (20), (14), and is easy to see from Fig. 2 and Fig. 3, the point of the $\rho$ minimum shifts toward greater $\beta$ values with the grating depth increase, while the minimum widens and deepens.

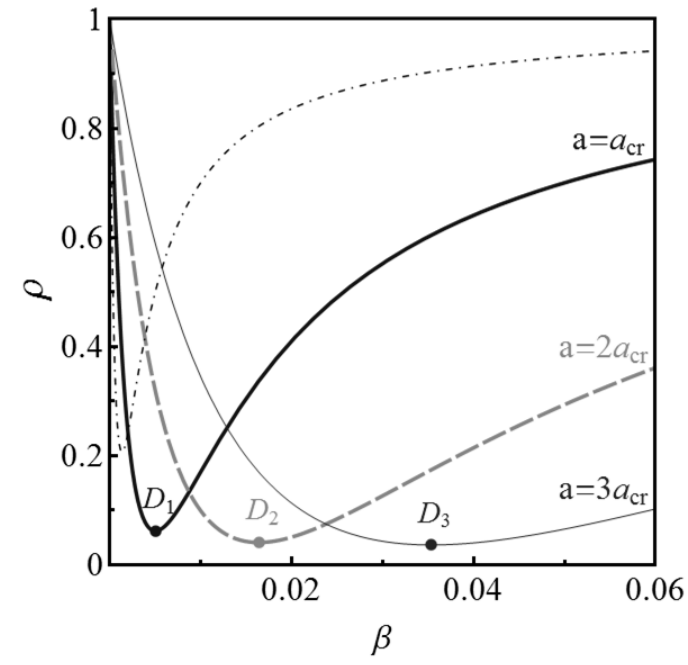

Fig. 2. The specular intensity $\rho$ dependence on the $\beta=\cos \theta$ is presented for three $\mathrm{Cu}$ harmonic gratings of equal period $d=200 \mathrm{mkm}$ and different depths $a$ indicated near the curves, and for the plane interface (dashand-dot curve). The calculations were performed for the wavelength $\lambda=300 \mathrm{mkm}$ ( $\xi=0.0009-0.001 \mathrm{i}$, [17]) so that the characteristic grating dimensionless parameters are $\kappa=1.5$ and $a_{c r}=0.037$. The points $D_{n}$, correspond to the $\rho$ minimal values for gratings of height $a=a_{n} \equiv n \cdot a_{c r}$, $n=1,2,3$, where $a_{c r}=0.037$ is the characteristic value of the dimensionless grating height, and are as follows: $D_{1}=(0.005,0.063), D_{2}=(0.016,0.041)$, $D_{3}=(0.035,0.037)$.

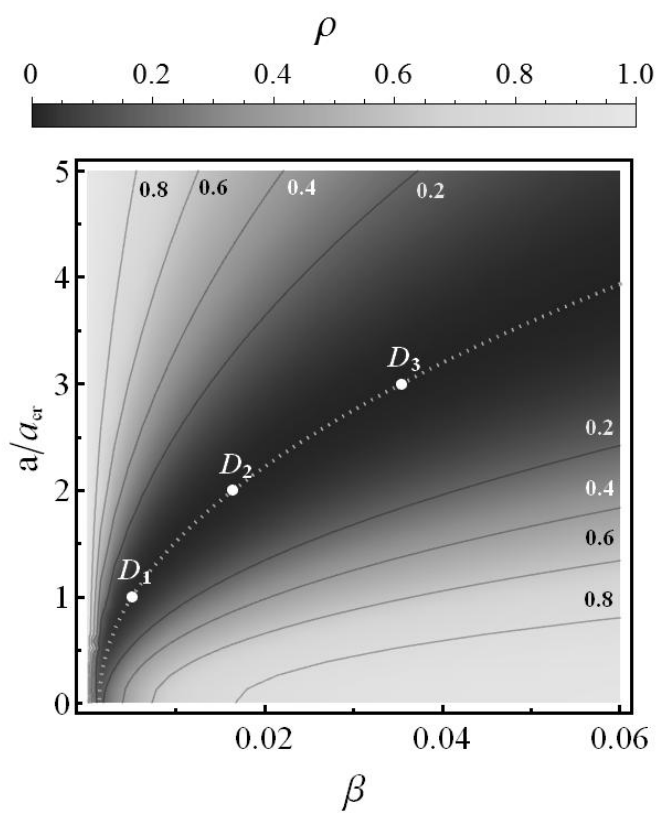

Fig. 3. The $\rho$ dependence on the grating depth and $\beta$ for $\mathrm{Cu}$ grating at $\lambda=300 \mathrm{mkm}, \quad \xi=(0.0009-0.001 i)$, $a_{c r}=0.037$. The dotted line corresponds to $\rho$ minimal values; $\rho$ contour curves are shown by solid lines. The points $D_{n}, n=1,2,3$, are indicated the same as in Fig. 2 caption. 
Note that reflectivity minimum is of rather general character and exists even for TM polarized wave incidence on unmodulated interfaces, $\Gamma=0, \xi_{\text {eff }} \Rightarrow \xi$ (when $h_{0}$ coincides with the corresponding Fresnel reflection coefficient $R=(\beta-\xi) /(\beta+\xi))$, cf. [16]. These properties present strict analogy to the reflectivity minimum from dielectric media existing under Brewster angle incidence [16]. In view of the fact that for $|\varepsilon|>>1$ (which is typical for good metals up to the frequencies of the visible range), the normal to the interface component of the wavevector in the metal half-space prevails essentially the tangential one, so the wave in the metal region can be formally considered as orthogonal to the interface. Consequently, under grazing incidence the reflected from the metal wave is approximately orthogonal to the "transmitted" one as it holds under Brewster angle incidence.

The specular reflectivity minimum, Eq. (21), becomes deep for relatively high effective losses, i.e., for $\xi_{\text {eff }}^{\prime}$ comparable to $\left|\xi_{\text {eff }}\right|$ (see Fig. 2). On the contrary, it approaches unity for vanishing losses, $\xi_{\text {eff }}^{\prime} \rightarrow 0$. Therefore, the effect of the specular reflection suppression under consideration is attributed to the cumulative (both active and radiative) losses maximum, cf. $[8,18]$. However, as it is shown below, the point $\beta=\beta_{\text {extr }}$ corresponds not only to the specular reflection minimum but results in well expressed maximal nonspecular efficiencies along with the active losses maximum. Evidently, if the only propagating diffracted wave is the specular one, then the grazing minimum is with necessity accompanied by maximal absorption.

It is of interest that normalized intensities of the propagating diffraction orders,

$$
\rho_{N}=\left|h_{N}\right|^{2} \frac{\operatorname{Re}\left(\beta_{N}\right)}{\beta}=4 W\left|U_{N}\right|^{2} \operatorname{Re}\left(\beta_{N}\right),
$$

present strongly nonmonotonic $\beta$ functions in accordance with the fast dependence of the subsidiary function, $W=W(\beta)$,

$$
W(\beta)=\frac{\beta}{\left(\beta+\xi_{\text {eff }}^{\prime}\right)^{2}+\left(\xi_{\text {eff }}^{\prime \prime}\right)^{2}} .
$$

It is easy to see that $W(\beta)$ achieves its maximal value, $W_{\max }$, strictly at the point $\beta=\beta_{\text {extr }}$,

$$
W_{\max }=W\left(\beta_{\text {extr }}\right)=\frac{1}{2\left(\left|\xi_{\text {eff }}\right|+\xi_{\text {eff }}^{\prime}\right)} \gg 1 .
$$

Respectively, intensities of all propagating waves (except the specular one) simultaneously achieve their maximal values at the point $\beta=\beta_{\text {extr }}$,

$$
\begin{gathered}
\rho_{N, \max }=\rho_{N}\left(\beta_{\text {extr }}\right)=\frac{2\left|U_{N}\right|^{2}}{\left|\xi_{\text {eff }}\right|+\xi_{\text {eff }}^{\prime}} \operatorname{Re}\left(\beta_{N}\right), \\
N= \pm 1, \pm 2, \ldots
\end{gathered} .
$$

This property is illustrated in Fig. 4, where the incident angle dependence of the minus first diffraction order intensity, $\rho_{-1}$, is shown for the geometry of Fig. 1 .

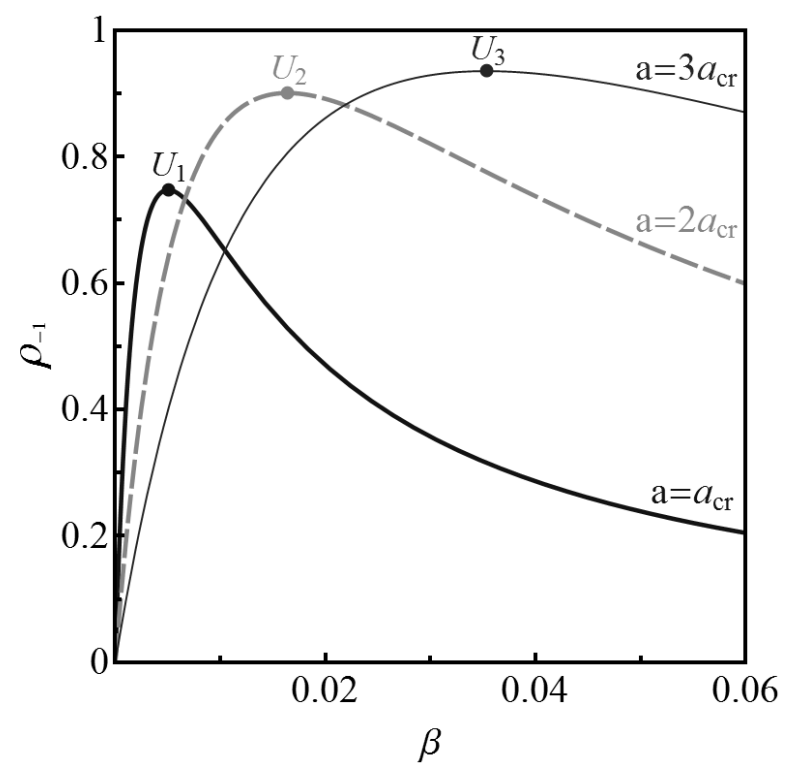

Fig. 4. The $\rho_{-1}$ plot versus $\beta$ for three harmonic gratings differing by depth with parameters indicated in Fig. 2 . The points $U_{n}$ correspond to the maxima related to gratings with $a=n \cdot a_{c r}, n=1,2,3$, respectively, and are as follows: $U_{1}=(0.005,0.749), U_{2}=(0.016,0.902)$, $U_{3}=(0.035,0.937)$.

In Fig. 5 the $\rho_{-1}$ dependence on $\beta$ and the grating height is demonstrated for the conditions coinciding with those of Fig. 3. It illustrates not only the anomaly shift to greater $\beta$ and widening with the grating height increase, but also the $\rho_{-1}$ value in a wide range of the crucial parameters. 


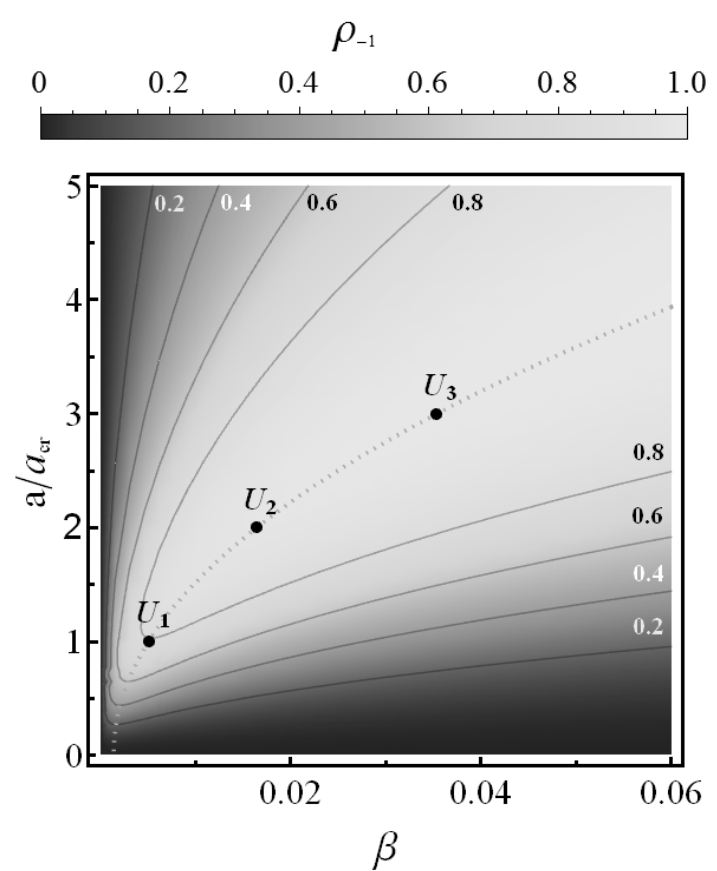

Fig. 5. The $\rho_{-1}$ dependence on the grating depth and $\beta$ for $\mathrm{Cu}$ gratings at $\lambda=300 \mathrm{mkm}, \quad \xi=(0.0009-0.001 i)$, $a_{c r}=0.037$. The dotted line corresponds to maximal values, solid lines depict $\rho_{-1}$ contour curves with levels attached.

One can see from Fig. 6 as well as from Fig. 2 and Fig. 4 that the positions of the $\rho_{-1}$ maxima coincide with high accuracy with those of $\rho$ minima. In addition, this point corresponds to the maximum of the absorption $A$ discussed in detail below.

The total energy flux outgoing with the propagating waves does not exceed that of the incident wave, i.e.,

$$
\sum_{N} \rho_{N} \leq 1
$$

where $\rho_{0}$ stays for $\rho$. The difference between the sum and unity, $A=1-\sum_{N} \rho_{N}$, is the active losses per unit area. The inequality for the solution presented is to be true under rather general conditions, specifically for such $\beta$ and $\kappa$ values that are far from anomalies related to all diffraction orders except the specular one. If the active losses are absent, then the inequality transforms into the equality. In the specific case of short-period gratings, such that $\kappa>2$, all diffracted orders except zeroth one with necessity correspond to evanescent waves. Under such conditions the strong specular reflectivity suppression is accompanied by maximal absorption. The energy redistribution between outgoing waves and the dissipation strongly depends on the parameters of the problem, as one can see from the explicit solution.
Here abovementioned is illustrated for the simplest case when, in addition to the specular wave, only one diffracted order corresponds to the propagating (outgoing) wave. It can be realized if $1+\alpha>\kappa>1$, when the minus first order presents propagating wave, $\beta_{-1}>0$, and $\beta_{n}$ with $n \neq-1,0$ are pure imaginary. Specifically, under such condition, illustraterd in Fig. 1, the absorption, $A=1-\left(\rho+\rho_{-1}\right)$ for harmonic grating can be presented explicitly as

$$
A=\frac{4 \xi^{\prime} \beta}{\left(\beta+\xi_{e f f}^{\prime}\right)^{2}+\xi_{e f f}^{\prime \prime 2}} .
$$

It can be easily checked that $A$ possesses single maximum. Neglecting slow $\xi_{\text {eff }}$ dependence on $\beta$ one can make sure that the maximum is at the point $\beta=\beta_{\text {exr }}$, and is

$$
A_{\max }=\frac{2 \xi^{\prime}}{\left|\xi_{\text {eff }}\right|+\xi_{\text {eff }}^{\prime}},
$$

cf. point $L$ in Fig. 6. Evidently, the absorption vanishes if the medium is dissipation free, $\xi^{\prime}=0$. Under rather specific conditions $A_{\max }$ can be of order unity, that does not describe general case contrary to the statement in [18].

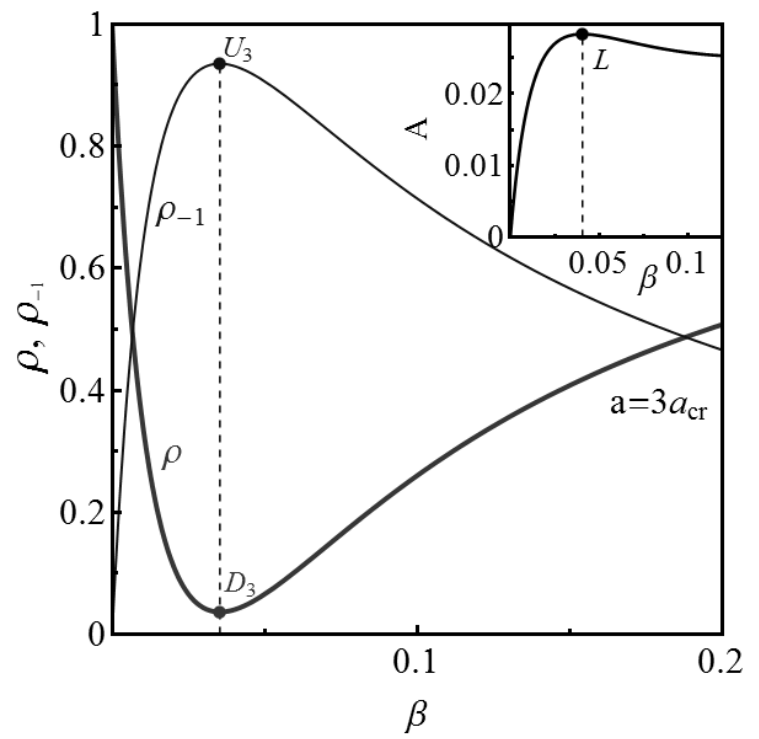

Fig. 6. The dependencies of the absorption, $A=1-\left(\rho+\rho_{-1}\right)$, and the intensities $\rho, \rho_{-1}$, on $\beta$ for $\mathrm{Cu}$ grating at $\lambda=300 \mathrm{mkm}, \xi=0.0009-0.001 i$, and the grating depth $a=3 a_{c r}, a_{c r}=0.037, \kappa=1.5$. The $D_{3}$ and $U_{3}$ values are the same as indicated in Fig. 2 and Fig. 4. The absorption maximum, $L$, is very low, $L=(0.04,0.02)$, approximately all energy of the incident wave is outgoimg with the minus first diffraction order. 


\section{Harmonic grating}

For the case shown in Fig. 1 only two diffraction orders correspond to the propagating waves - the specular and the minus first ones. Consider this specific subcase in more detail. Suppose additionally that the grating is harmonic one, i.e.,

$$
\begin{gathered}
\mu(x)=2 a \cos (g x) ; \quad \mu_{1}=\mu_{-1}=a>0, \\
\mu_{n}=0 \text { for }|n| \geq 2
\end{gathered}
$$

Then, approximating $b_{ \pm 1}$ by $\beta_{ \pm 1}$, and taking into account that $\beta_{ \pm 1}^{2} \simeq-\kappa^{2} \mp 2 \kappa$ at the point $\beta=0$, we find

$$
\Gamma \simeq \kappa^{2} a^{2}\left[\frac{1}{\sqrt{\kappa(2-\kappa)}}-i \frac{1}{\sqrt{\kappa(2+\kappa)}}\right]
$$

Since specular reflectivity possesses rather expressed minimum, for relatively low active losses the incoming energy is redirected into other propagating waves. The most interesting case that allows obtaining rather strong grazing anomalies presents such one that,

$$
|\Gamma| \gg|\xi|
$$

but $|\Gamma| \ll 1$, i.e., the case when the effective impedance is mostly caused by the diffraction rather than by the medium properties. It is of the essence that the supposition presented in Eq. (32) does not contradict the shallow character of the grating, $|\Gamma| \sim a^{2} \ll 1$, in view of the surface impedance smallness, $|\xi| \ll 1$. The characteristic value of the dimensionless grating height, $a_{c r}$, defined so that for $a=a_{c r}|\Gamma| \sim|\xi|$, is small, $a_{c r}=\sqrt{|\xi|} \ll 1$. Under Eq. (32) condition (equivalent to $\left.1 \gg a \gg a_{c r}\right) \rho_{-1, \max }$ and $\rho_{\min }$ can be rewritten as

$$
\rho_{-1, \max } \simeq \frac{2 \Gamma^{\prime}}{\beta_{-1}^{2}\left(|\Gamma|+\Gamma^{\prime}\right)}, \quad \rho_{\min } \simeq \frac{|\Gamma|-\Gamma^{\prime}}{|\Gamma|+\Gamma^{\prime}},
$$

or, in view of Eq. (33),

$$
\begin{gathered}
\rho_{-1, \max } \simeq \frac{2 \sqrt{2+\kappa}}{2+\sqrt{2+\kappa}} \equiv \rho_{-1, \mathrm{lim}}, \\
\rho_{\min } \simeq \frac{2-\sqrt{2+\kappa}}{2+\sqrt{2+\kappa}} \equiv \rho_{-1, \lim }, \quad \rho_{-1, \mathrm{lim}}+\rho_{\lim } \simeq 1
\end{gathered}
$$

So, for rather deep gratings, such that $a \gg a_{c r}$ (but still $a \ll 1$ ), the energy redistribution does not depend on the grating height, the quantities $\rho_{-1, \max }$ and $\rho_{\text {min }}$ achieve their asymptotic values depending on the geometrical parameters and the wavelength through the dimensionless combination $\kappa=\lambda / d$ only.

\section{Anomalous diffraction points.}

We illustrate position of other points corresponding to diffraction anomalies related to the interface of metal and isotropic lossless dielectric (vacuum, for simplicity). It is convenient to consider them in terms of the dimensionless normal component $\beta$ of the corresponding diffraction order. The point $\beta=-\xi_{\text {eff }}$ in the $\beta$ plane, Fig. 2, shows corresponding diffraction order pole caused by the surface plasmon polariton (SPP) mode. Note, the specific value of $\xi_{\text {eff }}$ for a given grating depends on the "resonance" diffraction order, see Eqs. (14), (15). In Fig. 7, only the vicinity of the corresponding Rayleigh point (that is of main interest in view of the diffraction anomalies), $|\beta| \ll 1$, is shown. With the change of the parameters of the problem, the $\beta$ value for each diffraction order can be either pure real positive (propagating wave) or pure imaginary (evanescent wave). The exception here presents the case when $\beta$ corresponds to the incident wave, so that $\beta$ is pure real, $0<\beta \leq 1$. These cases are separated by the Rayleigh (branch) point, $\mathrm{R}, \beta=0$. Other characteristic points, $\beta_{S P P}=-i \operatorname{Im}\left(\xi_{\text {eff }}\right)$ and $\beta_{G A}=\left|\xi_{\text {eff }}\right|$ related to the SPP resonance and to the grazing anomaly (GA), respectively, are shown by circles. If $\beta$ corresponds to the incident wave, then it is pure real and only GA point is actually of interest.

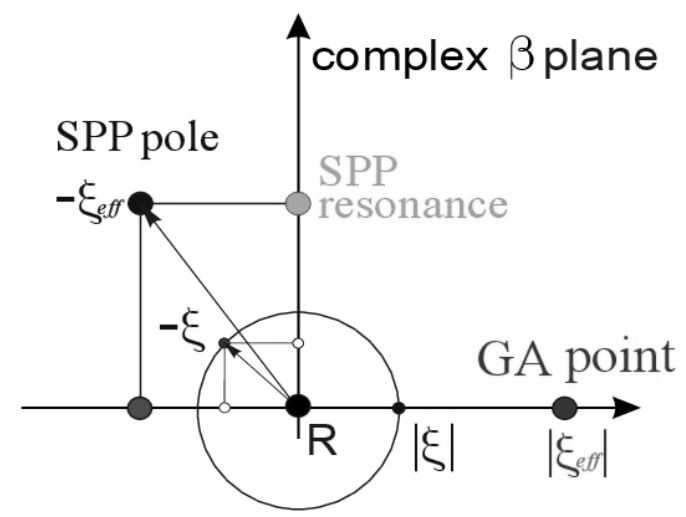

Fig. 7. Beta plane for some diffraction order.

\section{Conclusion}

1. The detailed analytical approach to the theoretical analysis of the diffraction anomalies is presented. 
2. It is shown that the diffraction of TM polarized wave at the high reflecting gratings under grazing incidence can result in deep suppression of the specular reflection accompanied by considerable redirection of the incoming energy to other propagating diffracted waves.

3. It is proved that the suppression of the specular reflection for TM polarization at grazing incidence is analogous to that at the Brewster angle.

4. In the case of arbitrary polarized incident wave, only TM component can experience the anomalous properties discussed. Due to the grating shallownes the TE radiation is not affected by the grating and thereby is nearly totally reflected. Thus, strong polarization transformation of specular reflection can occur.

5. It is worth noticing that essential enhancement of the grazing wave for nongrazing incidence is related to the problem under consideration by the reciprocity theorem, $[19,20]$. For instance, reversing the propagation direction of the minus first order diffracted wave in Fig. 1 we arrive at the reciprocal diffraction problem. In the latter the corresponding minus first order is related to the grazing wave propagating in the opposite direction to the incident wave in the primordial problem.

\section{References}

1. R. W. Wood, XLII., Philos. Mag. 4, 396 (1902)

2. Lord Rayleigh, III. Philos. Mag. 14, 60 (1907); Proc. Roy. Soc. A 79, 399 (1907)

3. U. Fano, JOSA 31, 213 (1941)

4. A. Hessel and A. A. Oliner, Appl. Opt. 4, 1275 (1965)

5. R. W. Wood, Phys. Rev. 48, 928 (1935)

6. G. M. Gandelman, P. S. Kondratenko, JETP Lett., 38, 246 (1983).

7. G. Korn, S. Poize, R. Giither, L. Schaefer, and L. Tesch, Sov. J. Quantum Electron. 15 (1), Jan. 1985

8. A. M.Tymchenko, V.K. Gavrikov, I.S. Spevak, A. Kuzmenko, A. V. Kats, Applied Physics Letters 106, 261602 (2015); doi: 10.1063/1.4923419

9. R. Petit, M. Neviere, Light propagation in periodic media. Differential Theory and Design, Marcel Dekker publisher, New York (2003).

10. Osamu Takayama et al, Electromagnetics, 28, Issue 3 (2008). dx.doi.org/10.1080/02726340801921403

11. A. V. Kats, V. V. Maslov, JETP, 62, No. 2, 496 (1972).

12. Alexandre V. Tishchenko, 14 September 2009, 17, No. 19, Optics Express 17102 (2009).

13. A. V. Kats, P. D. Pavitskii, I. S. Spevak, Radiophysics and Quantum Electronics, 35, No. 3-4 (1992).

14. A. V. Kats, P. D. Pavitskii, I. S. Spevak, JETP, 78, No. 1, p.79 (1994).

15. A. V. Kats and I. S. Spevak, Phys. Rev. B 65, 195406 (2002). DOI: 10.1103/PhysRevB.65.195406.

16. L. D. Landau and E. M. Lifshits, Electrodynamics of continuous media. (Pergamon, Oxford, 1977).

17. E. D. Palik ed., Handbook of Optical Constants of Solids,Academic, Orlando, 1985.
18. Eugene K. Popov, Lyuben B. Mashev, and Erwin G. Loewen, APPLIED OPTICS 28, No. 5 (1989).

19. R. J. Potton, Rep. Prog. Phys., 67, No. 7, pp. 717-754 (2004).

20. A. A. Kuzmenko, A. V. Kats, International Young Scientists Forum on Applied Physics (YSF-2015). 